\section{SENSITIVITY OF THE EAR}

$\mathrm{T}$ HE difficulty in securing accurate values of the minimum stimulus that the ear can detect is great. In the first place there are differences in the hearing mechanisms of various individuals tested. Except for those with some definite hearing defect, these differences largely depend on age; as one grows older the response of the ear becomes less, chiefly at the higher frequencies. Measurements of minimum hearing stimulus thus vary with the age of those being tested. Another difficulty is in measuring the minimum stimulus. According to an article by W. A. Munson (Beill Lab. Rec., 21, No. 10; June 1943) two references have been widely used. One is the rms. pressure of the sound wave at a point in a free sound field where the listener's ear will later be placed. This is the simpler of the two, and is particularly applicable to studies of the usual mode of hearing, that is, without the use of telephone receivers or similar devices. The other is the pressure at the ear-drum. This reference avoids uncertainty as to how the pressure, measured in the air previously to the listening test, would be modified at the ear-drum by the head and ear of the listener, and is particularly useful in studying the mechanism of hearing. It involves great technical difficulties, however, since the space in front of the ear-drum is small and almost inaccessible.

Regardless of which of these two methods is used, the pressure involved is very minute-less than 1/1,000 dyne/sq. cm. A pressure of this order of magnitude distributed over the ear-drum results in a force of the order of only $1 / 10^{8} \mathrm{oz}$. As an organ for detecting pressure changes, the ear is thus far more sensitive than our tactile organs, since a touch of this lightness would be imperceptible. Even at the upper limit of hearing, the force is only some thousandths of an ounce. Vibrating pressures greater than this become tactable rather than audible and result in the sensation of pain. Any air wave with an rms. pressure above the threshold value enters our consciousness as sound, and the sound becomes louder the higher the pressure. Since it is the loudness rather than the pressure that we are directly conscious of, some scale for measuring loudness is also desirable.

The results of a large amount of work were summarized some years ago by Fletcher and Munson and it was decided to use the loudness of a 1,000-cycle tone as a reference. This frequency is widely used as a test tone throughout the Bell System, and it has the advantage of being very close to the frequency range for which the ear is most sensitive. Since in general the relationship between the magnitude of a sensory response and its stimulus is logarithmic, it seemed desirable to use a logarithmic scale, and for convenience the loudness-level of a 1,000-cycle tone was arbitrarily taken to be the intensity level. Loudness-level at any other frequency or combination of frequencies is taken to be equal to the intensitylevel of a 1,000-cycle tone that sounds equally loud. Although loudness-level is measured on a logarithmic scale, and thus corresponds in magnitude to a decibel scale, the unit is called a phon instead of a decibel to indicate that the thing measured is basically different from power.

At 1,000 cycles the threshold of hearing in a free field is just about at 0 intensity-level, which also justifies making the loudness-level and intensity-level equal by definition at this frequency. At 1,000 cycles, therefore, an increase in intensity-level results in an equal increase in loudness-level. This equality is found not to exist at other frequencies, however.

To the question: How little do we hear? the only safe answer is : it all depends. What we hear is a sequence of periodic pressure changes in the air, but how small the pressure changes may be, given a normal young ear, depends on the rapidity of the changes. The ear is most sensitive when the pressure cycles are occurring at rates between 1,000 and 5,000 times per second, since we can then detect changes of less than a thousandth of a dyne/sq. cm. At both higher and lower frequencies, the sensitivity falls off. The studies that have determined these minimum perceptible pressure changes, and the many others that have established units of measurement and adequate techniques and apparatus, have provided the foundations for the extensive studies of hearing that have been carried on in the Laboratories.

\section{CERAMICS FOR HIGH-FREQUENCY INSULATION}

A CCORDING to an article by M. D. Rigterink (Bell Lab. Rec., 21, No. 9; May 1943) electrical poreelains which are satisfactory and useful materials for low-frequency currents have been replaced for high-frequency currents by new ceramic materials which have far smaller power factors. This replacement becomes absolutely essential at elevated temperatures such as are encountered in power vacuum tubes in which the insulator operates almost red hot. The power factor of most ceramics increases very markedly with increase in temperature, this causing more conversion of electrical energy into heat and producing a cumulative effect which may lead to a breakdown in any but the very best materials.

The most widely used of the improved ceramics are the steatites, this term now being applied to all synthetic ceramic materials which are prepared with talc as the principal raw material and which have magnesium metasilicate as the principal crystalline phase. Steatite bodies are prepared from mixtures of 60 per cent or more talc, 30 per cent or less kaolin, and the remainder usually of alkali or alkaline earth oxides or compounds that will decompose to give these fluxing oxides. The formed ware is heated from 1,200 to $1,400^{\circ} \mathrm{C}$. on a controlled, heating and cooling cycle. During this heat treatment the fluxing oxides combine with part of the magnesia, alumina, and silica given by the talc and the clays to form glasses which in turn disselve more of these constituents as the temperature rises. In addition to glass formation, chemical reactions take place between the solids and between the solids and liquid glasses; crystallizations also occur as the temperature is lowered, and finally crystalline transformations are produced. These complex changes cause the mixture to shrink and to become the hard, dense material known as a steatite ceramic.

Dielectric properties of the steatite ceramics vary considerably, depending on the amount, kind and proportions of fluxing oxides that are used in their preparation. The alkalis are particularly detrimental, and the alkaline earth oxides appear to be especially beneficial. Other variations are caused by the grinding and mixing of the raw materials, the firing cycles, and the nature and the amount of impurities present. All the steatites have unusually 
high transverse, tensile, and compressive strengths, these values frequently being as much as three times as high as the corresponding values for electrical porcelains. They also possess resistance to cold flow, ability to withstand high temperatures, resistance to all common chemical agents except hydrofluoric acid, and low porosities.

Steatites have replaced porcelains for some uses solely because of their greater mechanical strength but more frequently on account of their improved dielectric properties. The useful range of dielectric constant for steatite ceramics varies only from five to eight. Loss of electrical energy in these insulators depends more on the power factor than on the dielectric constant.

Another interesting and important property of these steatite ceramics is that those which have good insulating properties for direct current may not be as satisfactory for alternating current. For example, ceramic bodies with the same direct current resistances were prepared for which the values of $\tan \delta$ at $100 \mathrm{kc}$. varied by a factor of more than twenty-five. Thus, where a.c. and d.c. voltages are superimposed the dielectric properties for both have to be considered in comparing different materials.

\section{FORTHCOMING EVENTS}

(Meetings marked with an asterisk are open to the public)

\section{Saturday, October 16}

Instipute of Physios (X-RAY ANALYsis GRodP) (joint meeting with the MANCHESTER AND DISTRICT BRANCH) (in the Physies Depart ment, The University, Oxford Road, Manchester), at 2.30 p.m.- Si Lawrence Bragg, F.R.S. : “The Physical Opties of X-Ray Analysis" Short Papers and Exhibition of Apparatus, etc., relating to Industrial
Problems.

Association of SoIentific Workers (NORTh-West AREA) (in the College of Technology, Sackville Strect, Manchester).- Sir Robert Watson Watt, F.R.S.: "The Freedoms of Science".

\section{Sunday, October 17}

Association of SCIFNTIFIC WORKERS (NORTH-WEST AREA) (in the University, Liverpool) - Sir Robert Watson Watt, F.R.S.: "The
Freedoms of Science".

\section{Monday, October 18} ROYAL GEOGRAPHICAL SocreTY (at Kensington Gore, London,
S.W.7), at 5 p.m.-Dr. E. C. Willatts: "Physical Names for the Map of Great Britain".

\section{Tuesday, October 19}

SOCTETY OF CHEMICAL INDUSTRY (AGRICUITURE GROUP) (at the London School of Hygiene and Tropical Medicine, Keppel Strcet, Gower Street, London, W.C.1), at 2.30 p.m.--Mr. W. Morley Davies "Lime in Agriculture".

Institumion of Professional Civin Srrvants (at the Institution of Mechanical Engineers, Storey's Gate, St. James's Park, London, S.W.1), at 5.30 p.m. -The Rt. Hon. Sir Stafford Cripps, P.C.: "Radio S.W.1), at 5.30 p.m. -The Rt,

RoYal Photographio Soctity (SCTENTIFIC AND TECHNical GROUP) (at 16 Princes Gate, South Kensington, London, S.W.7), at 6 p.m.Dr. G. W. W. Steveng and Mr. P. C. Smethurst: "High-Resolution Microphotography-Graticules".

\section{Friday, October 22}

Instimution of Meghantoat ENGINenRs (at Storey's Gate, St. James's Park, London, S.W.1), at 5.30 p.m.-Prof. F. C. Lca : Presidential Address.

Friday, October 22-Saturday, October 23

Town and Country Planning Assoclation (at the Royal Empire Society, Northumberland Avenue, London, W.C.2). - Conference on "Country Towns in a National Planning Policy"

Friday, October 22-Sunday, October 24

INSTITUTR OF INDUSTRIAL ADMINISTRATION (at the Waldorf Hotel, Aldwych, London, W.C.2).-C Conference on "Management in Action".

Saturday, October 23

SHEFrield METAliURGiCal Assodation at 2.30 p.m.-Discussion on "The Education and 'Training of Metallurgists" (to be opened by Dr. Edwin Gregory)

\section{APPOINTMENTS VACANT}

APPLICATIONS are invitcd for the follcwing appointments on or before the dates mentioned:

Teacher of Mathematios and Genkral Sorence for Technical Day School and College The Chief Education Officer, Education Offices, Park Road, West Hartlepool (October 20).

EdUcational PsYchologist (full-time)-The County Medical Officer, Public Health Department, Shire Hall, Nottingham (October 20).

Assistant Agricultorat Chemist - The Principal, Agricultural Institute and Experimental Station, Kirtcn, Bcston, Iincs. (October 21).

TEACHER OF PHysics-The Principal, Acton Technical College, High

LeCTURER (full-time) in Physical and Inorganic Chemistiry, and a LEOTURER (full-time) IN ZOOLOGY, WITH BOTANY OR PHYSIOJOGYThe Clerk to the Governors, Scuth-East Essf X Techniral College and School of Art, Longbridge Road, Dagenham, Essex (October 22).

LEOTURER IN MINING-The Clerk to the Governors, Technical College, Inflrmary Road, Chesterfleld (Octoler 23).

LeOTURER IN Generat ScInNCr for the Junior Technical CollegeThe Principal, Derby Technical College, Normanton Road, Derby (October 23).

LeCTURER IN MATBEMATICS, and an Assistant MAster to teach ScIENCE and subsidiary MATHEMaTics-The Principal, Kingston Technical College, Kingston, Surrey (October 25)

TEACHER OF ENGINEERING SUBJECTS, and a TEACHER OF GEOGR.APHY - The Principal, West Ham Municipal College, Romford Road, Stratford, London, E.15 (October 25).

AssistanT TO THE ADVISORY MYCOLOGIST-The Advisory Mycologist, School of Agriculturc, Cambridge (October 30).

ENGINEERING GRADUATE (or equivalent qualiflcations) to teach chiefly Mechanical Subjects-The Principal, County Technical College,

Assistant Engineer for the British Gujana Fublic Wojks Department-The Ministry of Labour and Naticnal Service, Central (Technical and Scientific) Register, Alexandra Hcuse, Kingsway, London, W.C.2 (quoting Reference No. F.767).

\section{REPORTS and other PUBLICATIONS}

(not included in the monthly Books Supplement)

\section{Great Britain and Ireland}

Institute of Statistics, Oxford. Supplement No. 5, Bulletin Vol, 5, New Plans for International Trade. Pp. 40. (Oxford: Basil Blackwell.) 1s.6d.net. Royal Institute of Chemistry of Great Britain and Ireland. Iccture on Leather. By Dr. Dorothy Jordan-LIoyd, Pp. 31. (London : Roya Institute of Chemistry.)
[219 Hannah Dairy Research Institute. Report for the Two Years endHannah Dairy Research Institute. Report for the Two Years end-
ing 3lst March 1943. Pp. $20+4$ plates. (Kirkhill: Hannah Dairy Research Institute.) P. $20+4$ plates. (Kirkhill: Hannah Dairy Geological Survey of Great Britain. Wartime Pamphlet No. 35 . Detcrmination of Tin, with Special Reference to Tin Ores. By C. 0 . Detcrmination of Tin, with Special Reference to Tin Ores. By C. O.
Harvey. Pp. 13. (London: Geological Survey and Museum.) $9 d$. [219 Imperial Agricultural Bureaux. Report on the Imperial AgriImperial Agricultural Bureaux. Report on the Imperial AgriRt. Hon. Lord Hankey. Pp. 38. (London: H.M. Stationery Office.) Rt. Hon. Lord Hankey. Pp. 38. (London. H.M. Stationery Office.
[229

\section{Other Countries}

Indian Forest Bulletin. Utilisation (Ncw Series), No. 118: Studies in Fire Resistance, Part 1: The Fire Resistance of some Indian Timbers (a) The Rate of Burning. By D. Narayanamurti and $\mathbf{R}$. Gopalachari. Pp. 17. (Dehra Dun: Forest Research Institute.) 6 annas; $9 d$. Indian Forest Leaflet. Utilization, No. 89 : Bamboo Pill or Oint-

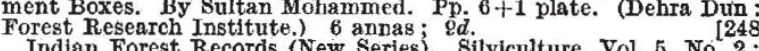
Indian Forest Records (New Series). Silviculture, Vol. 5, No. 2: Teak Plantation Technique. By A. L. Griffth. Pp. 123-220 + 19 plates (Delhi : Manager of Pablications.) $4 \cdot 2$ rupees; $68,6 d].[248$ Indian Forest Leaflet. Timber Development Branch, No. 36 annas : 9d. Silviculture, No 38: Harrison. Pp. Hre and Frosion. By Jag. damba Prasad. Pp. iii +9. 4 annas; $5 d$. (Dehra Dun : Forest Research Institute.)

Determinacao quantitativa do aluminio: sua precipatacno por [308 da fenilhidrazina. Pelo Wolfrando Carvalho de Moraes Bastos, Pp. 54. (Rio de Janeiro: Instituto Nacional de Tecnologia.) [69 cientifle and Industrial Research Pp 44. (Wellington: Goverivent

Parliament of the Commonwealth of Anstralia Sixteenth $[60$ Report of the Council for Sclentitic and Australia. Sixteenth Annua Year ended 30th June 1942. Pp. 74. (Canberra : Government Printer.) $38.3 d$

New Zealand: State Forest Service. Annual Report of the Oirecto of Forestry for the Year ended 31st March 1943. Pp. 24. (Wellington: Government Printer.) 9d. American Museum of Natural History. Seventy-fourth Annual Report for the Year 1942. Pp.ii $+65+8$ plates. (New York : American Museum of Natural History.) ] Five Editorials reprinted from Natural History Magazine, By Albert E. Parr. Pp. 20. (New York : American Museum of Natura]
History.) 